\title{
DO INDONESIANS DARE TO TRAVEL DURING THIS PANDEMIC?
}

\author{
Rahmawati RAHMAWATI* \\ Mulawarman University, Faculty of Economics and Business, Department \\ of Management, Samarinda, Indonesia, e-mail: rahmawati@feb.unmul.ac.id \\ Gusti Noorlitaria ACHMAD \\ Mulawarman University, Faculty of Economics and Business, Department \\ of Management, Samarinda, Indonesia, e-mail: gusti.noorlitaria.achmad@ feb.unmul.ac.id

\section{Doddy ADHIMURSANDI} \\ Mulawarman University, Faculty of Economics and Business, Department \\ of Management, Samarinda, Indonesia, e-mail: doddy.adhimursandi@feb.unmul.ac.id
}

\begin{abstract}
Citation: Rahmawati, R., Achmad, G.N., Adhimursandi, D. (2021). DO INDONESIANS DARE TO TRAVEL DURING THIS PANDEMIC? GeoJournal of Tourism and Geosites, 38(4), 1256-1264. https://doi.org/10.30892/gtg.38433-767
\end{abstract}

\begin{abstract}
The Covid-19 pandemic that has hit the world has devastated the tourism sector. In Indonesia, the government continues to focus on bringing in tourists from various foreign countries. This study tries to explain whether Indonesian people dare to travel and what factors influence their intention to travel. We applied an explanatory quantitative approach in this study, where the survey supported online by involving 200 respondents spread throughout Indonesia. Characteristics of their age between 17 years - 60 years. SEM method for interpreting data. The findings of the analysis present that during pandemic, Indonesian people continue to travel by paying attention to Covid-19 health procedures. In addition, they also consider supporting factors such as traveling needs, safety during the traveling, and exist on social media needs that significantly influence traveling intention of traveling interest mediation. Family economic condition is a factor that plays a very important role in encouraging traveling intention because we proved it to be a moderating variable that has a significant effect on traveling interest in traveling intention. The interesting thing is that $94 \%$ of respondents did not reduce their desire to travel in 2021.
\end{abstract}

Key words: traveling intention, traveling need, safety during traveling, exist on social media need, family economic condition, SEM

$* * * * * *$

\section{INTRODUCTION}

The Covid-19 that has hit the world since the beginning of 2020 has not yet ended. In fact, in Indonesia, the number of new patients is increasing every day. WHO (2021) projects that Covid-19 can only control for the next five years? This pandemic has also shaken the Indonesian economy and, if it really takes a long time, then economic conditions will be difficult to rise. Covid-19 also affects business conditions in various sectors (Pusriadi et al., 2021). Tourism and hospitality are some sectors most affected by this pandemic. Many hotels and restaurants went bankrupt because the government issued a national or regional lockdown policy aimed at suppressing the spread of the virus. During the pandemic that hit almost a year in the past, many tourist attractions were closed or closed by themselves because most tourists did not dare to visit various destinations. The impact on tourists amid this great shock fell by $80 \%$. By 2020 , the number of foreign tourists who came to Indonesia only reached 4 million people. In fact, in 2019, the visit rate reached 16.1 million. As a result, the value of foreign exchange generated from the tourism sector also dropped dramatically, from 16.9 billion USD to 3.54 billion USD (Purba et al., 2021). The policy of banning foreign tourists has really hit the intensity of foreign tourist visits.

However, with Indonesia's enormous population, this is a very potential market, which can encourage tourism to remain passionate by relying on visits from domestic tourists (Rahmawati et al., 2021). Of course, by implementing new normal tourism through tightening health procedures to prevent Covid-19. This study seeks to reveal how the trend of Indonesia's tourism conditions in the future, especially during the Covid-19 pandemic. Important considerations include the interests and intentions of tourist visits the Indonesian people will carry that out and try to see some factors that influence them.

Why do we see interest and intention to do tourism, of course, it can be a predictor for tourism conditions in Indonesia? These two aspects are steps that are close to the actual action in the decision-making process. This study also tries to explain information about related matters, such as preferences for the type of tourism that prospective domestic tourists want to visit, tourist destinations, and perceptions about where to go. The research applied by identifying the trend of family economic conditions (Indonesian people) in 2021. Of course, there is a potent reason that refers to the economic dimension as an important variable that affects the realization of tourism activities, how a person will travel if the economic condition is in a recession. In the motivational theory proposed by Maslow (1943), people will meet primary or physiological needs first before meeting needs that are more secondary or tertiary (Navy, 2020). For most Indonesians, traveling has not become a primary need, although it is also an important need to be fulfilled.

\footnotetext{
* Corresponding author
} 


\section{THEORETICAL FOUNDATION}

\section{Traveling Need}

Everyone likes tourism activities because traveling is a fun activity. By traveling, we will be fresh both physically and mentally. Through tourism activities, we will also get many exciting and memorable new experiences. For every individual, tourism is a necessity. They need tourism from children to parents. Tourism is also the need of all people, both the lower, middle, and upper classes (Ramadania et al., 2021). All need this activity because it can provide stimulation for health. Travel can stimulate excitement, reduce stress, and boredom, boosting the body's immune system.

For most people in the productive age segment, making tourism activities a means to escape for a moment of boredom and daily routines. They need to recharge their energy to face the pressure of the work to come. Apart from being a means of escaping, tourism is a reward for them after they have achieved certain performance. Tourism is not just a desire and an alternative, but a necessity (Perez and Juaneda, 2000). In Indonesia, the increasing middle-class economy has pushed the need for greater tourism. The middle class is no longer only focused on pursuing consumer products. After basic needs such as houses and cars, they focus on achieving self-actualization, which can realize through travel, they travel, take photos, and then upload them to social media. Tourism has become a necessity for people of all economic circles and may have become part of a lifestyle. However, their difference lies in the destination or tourist destinations that can visit. For the lower middle class, they choose domestic destinations with short distances (Klijs et al., 2012). In the middle class, usually further or intercity, namely to Bali or Lombok. The high-end class, abroad such as Singapore, is a country that the uppermiddle class must visit. In this study, the indicators used to measure the traveling need variable are traveling as a primary need, traveling for life balance, and traveling for released stress (eg Sönmez and Graefe, 1998; Iso-Ahola, 1980).

\section{Safety during Traveling}

Covid-19 also experienced by Indonesia, where until now, the number of people infected is still high, and it is still relatively slow in handling it. This pandemic not only makes us afraid to do tourism activities but also affects the perception of safety risks and ultimately affects the intention to travel (Rittichainuwat and Chakraborty, 2019).

The safety of visitors is a priority because its role is very important in influencing interest in traveling. Don't let them exposed to the virus. The Indonesian government has issued health protocol rules so that visitors continue to pay attention to all policies related to limiting visits. This rule in a healthy protocol ratified through the Ministry of Health of the Republic of Indonesia Number HK.01.07/Menkes/382/2020 concerning "Health protocols for the community in public places and facilities in preventing and controlling Covid-19" (Ilmi et al., 2020). Visitors must ensure that they are in good health before making a visit. If you experience symptoms such as fever, cough, runny nose, sore throat, or shortness of breath, stay at home, immediately consult a health care facility if symptoms persist. Then, always wear a mask while at tourist sites. Maintain hand hygiene by frequently washing hands with soap and running water, or using hand sanitizer. Avoid touching facial areas such as eyes, nose, and mouth. Keep paying attention to keep your distance (at least one meter). When you get home, take a shower and change clothes immediately before coming into contact with family members at home. Clean cellphones, glasses, bags, and other items with disinfectant liquid. Safety during traveling strongly influenced by tourists' perceptions of the importance and willingness to comply with the regulation, so the four indicators that become benchmarks in the safety variable during traveling are personal health, willingness to comply with health procedures, security of tourist areas, and completeness of facilities to prevent Covid-19 transmission (Hayes, 2013; Slovic and Peters, 2016).

\section{Exist in Social Media}

Social media has become a necessity for most Indonesian people who already own and use smartphones in their daily lives. They recorded that out of 272.1 million Indonesians, uniquely, there are 338.2 million active mobile phone numbers. That number is much larger than the population compared to 175.4 million internet users and those who are active with social media 160 million (Maria et al., 2019). What are the habits of social media activists in Indonesia?

The average time spent accessing social media through various devices is 3 hours and 26 minutes per day, while social media applications accessed by Indonesian netizens are $88 \%$ from YouTube, $84 \%$ have WhatsApp, $82 \%$ on Facebook, 79\% on have WhatsApp, and 79\% of Instagram owners (Parahita, 2019). With the penetration of social media users in Indonesia and the enthusiasm, an average netizen uses over one type of social media, they conclude social media has become an inseparable part of internet users. Social media, apart from being a means to communicate or establish social relationships with other individuals, is also a means to show the existence of individuals. Using social media for most people is used to have fun, it also often used as a medium to publicize their activities, display goods for sale, share experiences of visiting a place, or even display netizens' own profiles as photos and videos. This becomes interesting if they associate it with the concept of existence in social media, within social media, getting attention and growing an image can categorized as self-existence (Nasrullah, 2018). Self-existence can interpreted as the existence of an individual's self, as evidenced by the recognition or assumption of others regarding their existence.

In the current era of technology, self-existence has a strong bond with the use of social media. In Indonesia, many netizens can do anything to be existing on social media. The number of followers, views, likes, and comments on content uploaded on social media illustrates this. If those want to exist on social media, they will continue to look for content that is interesting and will get positive reactions from people in the media circle (Syahputra and Hafiar, 2019). In fact, many netizens harmed by wanting to create content that they think many people will see. For example, teenagers fall into the sea while taking selfies they want to upload to Instagram, and teenagers get run over by a truck while creating content to upload to YouTube. This phenomenon can understand that whether social media exists is important 
for Indonesian netizens. The indicators applied to measure the variable need to exist on social media are always active on social media, consider it important to exist on social media, social media has become a primary need, and actively upload on social media (Hemsley et al., 2018; Edosomwan et al., 2011; Kapoor et al., 2018).

\section{Economic Family Condition}

The Covid-19 pandemic will continue for the next few years, suppressing the financial conditions of various business sectors in Indonesia (Jiuhardi et al., 2021). The direct impact also makes the economic condition of Indonesian families will also continue to decline if it continues in the long term. Family economic management is an action to plan, implement, monitor, evaluate, control the acquisition and use of family economic resources, especially finances, in order to achieve an optimum level of fulfillment of the needs of all family members, ensuring stability and family economic growth. The family economy is one of the smallest units of economic study from a larger economic system, such as companies and the state (Doriza, 2015). Saiful Mujani Research and Consulting (SMRC) in 2020 surveyed the family economy as part of the impact of Covid-19 because 3.05 million workers in Indonesia have laid off and experienced layoffs. As a result, 59\% of informants feel that the level of family welfare is getting worse day by day.

The family's economic condition is in terrible condition. The current condition of the community is at the stage of taking loans, meaning that to meet their basic daily needs, they have to borrow. Otherwise, they cannot fulfill their basic needs. This is a terrible condition. The needs of family members vary, such as daily consumption needs, educational funding needs for children, health needs, and other varied needs. If national economic conditions continue to decline and are not immediately stable, it will further worsen household economic conditions. For this study, we will identify it how the role of the family's economic condition factor as a moderating variable, so that it will see whether it can strengthen the magnitude of the influence of traveling interest in traveling intention. There are four indicators (family income stability, family income sustainability, family purchasing power, and family income adequacy) as instruments in the family economic condition variable (Gelan, 2003; Ajzen and Fishbein, 1980).

\section{Traveling Interest}

Tung and Ritchie (2011) define interest in tourism contexts as interest in purchasing products and services. Travel interest is a person's attitude tendency to carry out tourism activities or take actions related to tourism activities and measured by the level of possibility of a person to carry out tourism activities. Travel interest is part of the component of consumer behavior or a person's tendency to behave before the decision to travel actually implemented (Sirakaya et al., 1997). Kompas (2020) also recorded the public's desire to travel, which involved 1,200 respondents in the 17-59 year age range from all provinces in Indonesia. 38.5\% of respondents want to travel. The survey results also presented $21.7 \%$ of respondents stated: "want to travel". Meanwhile, another 16.8\% responded "really want to travel", $42.4 \%$ "do not want to travel", "really don't want to travel" reached $12.6 \%$, and $6.5 \%$ commented, "don't know".

Then, where do they want to travel? There are $28.4 \%$ of respondents who choose to do marine or marine tourism and $19.5 \%$ choose nature/ecotourism. Interestingly, $12.2 \%$ of respondents choose to shop and culinary tourism, the remaining 9.4\% want cultural and historical tourism, and $8.8 \%$ are actually interested in visiting urban/rural tourism. Alegre et al. (2011), Jang and Cai (2002), and Cohen and Areni (1991) focus on interests that are tailored to the tourism context. Broadly, tourism interest implemented through transactional interest, referential interest, preferential interest, and exploratory interest. These four dimensions are part of interest in traveling.

\section{Traveling Intention}

In theory, traveling intention defined as purchase intention. Explicitly, purchase intention plays an important role in studies that review consumer behavior, where purchase intention is a desire and tendency that strongly encourages individuals to buy a product (Bosnjak et al., 2006). Purchase intention is a motivational factor that drives individuals to buy certain products. Therefore, purchase intention is the best method to predict consumer behavior.

In line with the Theory of Reasoned Action (TRA), it assumed that consumed behavior determined by their own intentions (Fazekas et al., 2001). Dodds et al. (1991) reflect that purchase intention refers to a consumer's subjective judgment that fully evaluates to purchase a product or service. Zafar and Rafique (2013) demonstrated that consumer purchase intention is the desire and tendency of consumers to buy advertised products because there is a possibility that consumers will buy these products in the future. Liu et al. (2013) and Dwyer et al. (2004) focuses on purchase intention with four indicators that influence it, namely the possibility of consumers choosing, being encouraged to buy the product, trying, and wanting to buy it in the future. Especially in this study, it requires a change of indicators to suit the tourism context, so the relevant indicators are the intention to travel this year, planning time to travel, sufficient information about tourist objects to be visited, and budget for traveling.

\section{Hypothesis Design}

The Covid-19 pandemic has brought changes to consumer behavior towards buying a product. No exception to the behavior of tourists in visiting. When there is interest in traveling and have enough resources in normal times, potential tourists will do that. However, in this difficult situation, there are considerations related to health procedures that must be adhered to. Indeed, there are some people who feel uncomfortable with the regulation and also the declining economic conditions, which definitely affect their interest and intention to travel. Social media has become a lifestyle for most people. Continuing to exist on social media is an important thing to consider for them. In fact, teenage netizens can do 
things that can actually harm themselves to expect positive likes, views, and comments. Based on the current phenomenon, we build the conceptual framework illustrated in Figure 1. There are five proposed hypotheses:

H1: Traveling need has a significant positive effect on traveling interest;

H2: Safety during traveling has a significant positive effect on traveling interest;

H3: Exist in social need has a significant positive effect on traveling interest;

H4: Traveling interest has a significant positive effect on traveling intention;

H5: Family economic condition strengthens the influence of traveling interest in traveling intention.

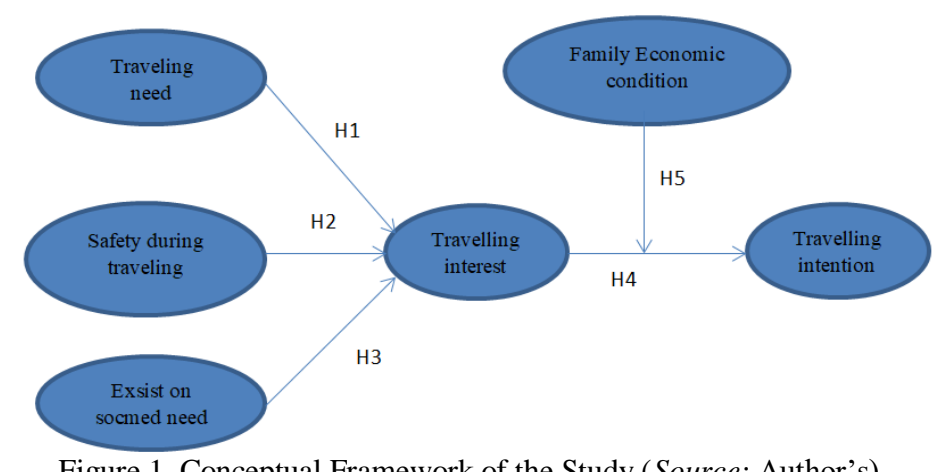

Figure 1. Conceptual Framework of the Study (Source: Author's)

\section{METHODOLOGY}

Sample

The quantitative approach became the basis for this research to prove several hypotheses that were designed (Behl et al., 2021). We apply data interpretation through the Structural Equation Model (SEM) with Analysis of Moment Structure (AMOS) software got from the survey results. Referring to the objectives to be achieved, this research included in the category of explanatory research, which requires empirical evidence of the effect of exogenous variables (traveling need, safety during the traveling, and exist in social need) on endogenous variables (traveling intention). We designed traveling interest as an intervening variable and family economic condition acts as a moderator variable.

The sample focused on Indonesian citizens aged 17 to 60 years. The respondents' provisions come from all economic segments and education levels, whether they have carried out tourism activities during the pandemic. We applied the survey online, so that simple random sampling met the criteria in tourism studies (e.g. Yuan and McDonald, 1990; Archer and Fletcher, 1996). The respondents' criteria may fill out the questionnaire which is distributed online. We conducted the survey during March-April 2021 with a distribution that met the criteria of 200 samples.

\section{Measurement}

Three vital parts to the questionnaire determine the feasibility of this study. The first instrument is about the demographics of the respondents and the second is a question that measures variables, where the indicators used are a combination of the thoughts of the authors and the adaptation of concepts by several credible experts. Third, openly answered questions based on respondents' opinions about traveling during the pandemic and recommendations to the government, so that tourist travel in Indonesia can survive. We base the rating scale in the questionnaire on a semantic differential scale. A scale of 1 (strongly disagree) to 10 (strongly agree), which is supported by ordinal data to be processed by statistical analysis tools (Witte et al., 1996). Table 1 describes the variables and indicators. The data generated from the online survey then summarized descriptively to present demographic information (Table 2). Important information that deserves to highlighted based on the survey results, that during the 2020 pandemic yesterday, $77 \%$ of respondents continued to carry out tourism activities, where the objects visited traveled to nature tourism (80\%) with a choice of tourist destination locations within the province. Interestingly, $38 \%$ of respondents actually continued traveling within the city and another $38 \%$ traveled outside the city (but still in the same province).

Regarding social media ownership, the average respondent has has over two social media, of which WhatsApp 95\%, Instagram $80 \%$, and Facebook $73 \%$ as the most popular social media for them. Overall, Indonesian people do not consider Covid-19 as a barrier for them to travel. $94 \%$ of respondents responded they want to travel in 2021 . Nature tourism is still the crucial choice and as an alternative, traveling is still safe if you obey the health procedures imposed by the government as stated by $59 \%$ of respondents. The perception of another $29 \%$ of respondents that traveling is currently unsafe and $10 \%$ consider traveling with strict protocols to be complicated.

\section{FINDINGS}

The normality test applies to the distribution of data that has a normal distribution or not. Normality test to observe the critical ratio (CR) on the results of the assessment of normality in the AMOS program. If the critical ratio is between -2.58 CR 2.58, then the data normally distributed (we met the normality assumption).

Table 3 shows that the multivariate $(C R)$ is 12,412 . This value is outside the range of $-2.58 \mathrm{CR} 2.58$, so can conclude that the data not normally distributed. Using SEM analysis is not too critical if over 100 observations based on the "central limit theorem" of a large sample can produce sample statistics that are close to the normal distribution (Ringle et al., 2020). Specifically, in this study, the total sample is 156 observations (data after outliers), so the data assumed to normally distributed. Validity concerns the level of accuracy achieved by an indicator in assessing something or the accuracy of the measurement of what should measure. The results of the validity test listed in Table 4.

As a result, it declared all indicators valid, where the loading factor presented in Table 4 is above 0.5 . As further information, reliability serves to present the internal consistency of the indicators in the construct, so that achievement can represent it and show a general construct (Table 5). 
Table 1. Variable Components and Indicators (Source: Author's)

\begin{tabular}{|c|c|c|}
\hline Variables & Code & Indicators \\
\hline \multirow{3}{*}{ Traveling need } & TN1 & Need traveling for released stress \\
\hline & TN2 & Traveling for life balance \\
\hline & TN3 & Traveling as a primary need \\
\hline \multirow{4}{*}{ Safety during traveling } & SDT 1 & Personal health \\
\hline & SDT 2 & Safety travel area \\
\hline & SDT 3 & Adherence to health procedure \\
\hline & SDT 4 & Availability of covid prevention facility \\
\hline \multirow{4}{*}{ Exist on socmed need } & EOM 1 & Activity on social media \\
\hline & EOM 2 & Important to be active on social media \\
\hline & EOM 3 & Social media is important thing in may life \\
\hline & EOM4 & Upload everythings in my social media \\
\hline \multirow{4}{*}{ Traveling interest } & TItr 1 & Consider going on to traveling \\
\hline & Titr 2 & Want to traveling \\
\hline & Titr 3 & Looking for travel information \\
\hline & Titr 4 & Have several tourism site alternative \\
\hline \multirow[t]{4}{*}{ Traveling intention } & TItn 1 & Have intention to traveling \\
\hline & TItn 2 & Have time planning \\
\hline & TItn 3 & Prepare traveling budget \\
\hline & TItn 4 & Have enough knowledge about tourism site to be visited \\
\hline \multirow[t]{4}{*}{ Family economic condition } & FEC 1 & Stability of family income \\
\hline & FEC 2 & Continuity of family income \\
\hline & FEC 3 & Family buying power \\
\hline & FEC 4 & Adequacy of family income \\
\hline
\end{tabular}

Table 3. Testing the Normality of the Data (Source: observation by Author's)

\begin{tabular}{|c|c|c|c|c|c|c|}
\hline Variable & Min. & Max. & Skew. & CR & Kurtosis & CR \\
\hline Y2.4 & 2.000 & 10.000 & -0.509 & -2.595 & -0.453 & -1.155 \\
\hline Y2.3 & 2.000 & 10.000 & -0.416 & -2.123 & -0.592 & -1.509 \\
\hline Y2.2 & 2.000 & 10.000 & -0.317 & -1.614 & -0.731 & -1.863 \\
\hline Y2.1 & 2.000 & 10.000 & -0.379 & -1.932 & -0.594 & -1.514 \\
\hline Y1.4 & 2.000 & 10.000 & -0.852 & -4.344 & 0.440 & 1.121 \\
\hline Y1.3 & 3.000 & 10.000 & -0.613 & -3.125 & -0.482 & -1.230 \\
\hline Y1.2 & 2.000 & 10.000 & -0.488 & -2.490 & -0.214 & -0.545 \\
\hline Y1.1 & 3.000 & 10.000 & -0.260 & -1.326 & -0.474 & -1.209 \\
\hline X3.1 & 2.000 & 10.000 & -0.406 & -2.072 & -0.547 & -1.396 \\
\hline X3.2 & 1.000 & 10.000 & -0.026 & -0.133 & -0.873 & -2.227 \\
\hline X3.3 & 1.000 & 10.000 & 0.142 & 0.726 & -0.821 & -2.093 \\
\hline X3.4 & 1.000 & 10.000 & -0.031 & -0.160 & -1.138 & -2.902 \\
\hline X3.5 & 1.000 & 10.000 & -0.158 & -0.804 & -1.088 & -2.775 \\
\hline X3.6 & 1.000 & 10.000 & 0.205 & 1.043 & -1.065 & -2.715 \\
\hline X2.1 & 3.000 & 10.000 & -0.753 & -3.840 & 0.127 & 0.323 \\
\hline X2.2 & 1.000 & 10.000 & -0.539 & -2.749 & -0.058 & -0.147 \\
\hline X2.3 & 1.000 & 10.000 & -1.041 & -5.308 & 0.479 & 1.222 \\
\hline X2.4 & 6.000 & 10.000 & -0.732 & -3.733 & -0.608 & -1.551 \\
\hline X2.5 & 3.000 & 10.000 & -0.825 & -4.206 & 0.251 & 0.640 \\
\hline X1.1 & 4.000 & 10.000 & -0.944 & -4.812 & 0.171 & 0.437 \\
\hline X1.2 & 4.000 & 10.000 & -0.806 & -4.108 & -0.010 & -0.024 \\
\hline X1.3 & 1.000 & 10.000 & -0.787 & -4.012 & 0.456 & 1.163 \\
\hline X1.4 & 2.000 & 10.000 & -0.527 & -2.686 & -0.668 & -1.704 \\
\hline Multivariate & \multicolumn{7}{|l}{} & & 67.400 & 12.412 \\
\hline
\end{tabular}

Table 4. Construct Validity (Source: observation by Author's)

\begin{tabular}{|l|l|l|l|l|}
\hline Variables & Indicators & Loading factors & Cut off & Decision \\
\hline
\end{tabular}

\begin{tabular}{|l|c|c|c|c|}
\hline Variables & Indicators & Loading actors & Cut off & Decision \\
\hline \multirow{3}{*}{$\begin{array}{l}\text { Traveling } \\
\text { need (X1) }\end{array}$} & $\mathrm{X} 1.1$ & 0.927 & 0.500 & Valid \\
\cline { 2 - 5 } & $\mathrm{X} 1.2$ & 0.969 & 0.500 & Valid \\
\cline { 2 - 5 } & $\mathrm{X} 1.3$ & 0.779 & 0.500 & Valid \\
\cline { 2 - 5 } $\begin{array}{l}\text { Safety } \\
\text { during } \\
\text { traveling } \\
\text { (X2) }\end{array}$ & $\mathrm{X} 2.1$ & 0.830 & 0.500 & Valid \\
\cline { 2 - 5 } & $\mathrm{X} 2.2$ & 0.771 & 0.500 & Valid \\
\cline { 2 - 5 } & $\mathrm{X} 2.3$ & 0.701 & 0.500 & Valid \\
\cline { 2 - 5 } $\begin{array}{l}\text { Exsist on } \\
\text { socmed } \\
\text { need (X3) }\end{array}$ & $\mathrm{X} 2.5$ & 0.637 & 0.500 & Valid \\
\cline { 2 - 5 } & $\mathrm{X} 3.1$ & 0.711 & 0.500 & Valid \\
\cline { 2 - 5 } & $\mathrm{X} 3.2$ & 0.901 & 0.500 & Valid \\
\cline { 2 - 5 } & $\mathrm{X} 3.3$ & 0.934 & 0.500 & Valid \\
\cline { 2 - 5 } & $\mathrm{X} 3.5$ & 0.830 & 0.500 & Valid \\
\hline \multirow{3}{*}{$\begin{array}{l}\text { Traveling } \\
\text { interest }\end{array}$} & $\mathrm{X} 3.6$ & 0.876 & 0.500 & Valid \\
\cline { 2 - 5 } (Y1) & $\mathrm{Y} 1.1$ & 0.558 & 0.500 & Valid \\
\cline { 2 - 5 } & $\mathrm{Y} 1.3$ & 0.828 & 0.500 & Valid \\
\cline { 2 - 5 } & $\mathrm{Y} 1.4$ & 0.928 & 0.500 & Valid \\
\hline \multirow{3}{*}{$\begin{array}{l}\text { Traveling } \\
\text { intention } \\
\text { (Y2) }\end{array}$} & $\mathrm{Y} 2.1$ & 0.909 & 0.500 & Valid \\
\cline { 2 - 5 } & $\mathrm{Y} 2.2$ & 0.960 & 0.500 & Valid \\
\cline { 2 - 5 } & $\mathrm{Y} 2.3$ & 0.955 & 0.500 & Valid \\
\cline { 2 - 5 } & $\mathrm{Y} 2.4$ & 0.916 & 0.500 & Valid \\
\hline
\end{tabular}

Table 2. Descriptive Statistics (Source: Author's)

\begin{tabular}{|c|c|c|}
\hline Informations & Frequency & $\%$ \\
\hline \multicolumn{3}{|c|}{ Age (years) } \\
\hline $17-25$ & 59 & $\overline{30}$ \\
\hline $26-45$ & 85 & $43 \%$ \\
\hline $45-60$ & 56 & $28 \%$ \\
\hline \multicolumn{3}{|c|}{ Education } \\
\hline
\end{tabular}

\begin{tabular}{|c|c|c|}
\hline \multirow{2}{*}{\multicolumn{3}{|c|}{$>$ High school }} \\
\hline & & \\
\hline High school & 49 & $25 \%$ \\
\hline Diploma 1 - Diploma 3 & 8 & $4 \%$ \\
\hline Bachelor & 78 & $39 \%$ \\
\hline Master & 35 & $18 \%$ \\
\hline Doctor & 26 & $13 \%$ \\
\hline
\end{tabular}

\begin{tabular}{|l|l|l|}
\hline Lecturer & 30 & $15 \%$ \\
\hline
\end{tabular}

\begin{tabular}{|l|c|c|}
\hline Housewife & 8 & $4 \%$ \\
\hline Govennent
\end{tabular}

\begin{tabular}{|l|c|c|}
\hline Government employees & 30 & $15 \%$ \\
\hline
\end{tabular}

\begin{tabular}{|l|l|l|}
\hline Professional & 23 & $12 \%$ \\
\hline
\end{tabular}

\begin{tabular}{|l|l|l|}
\hline Private employees & 64 & $32 \%$ \\
\hline
\end{tabular}

\begin{tabular}{|c|c|c|}
\hline Entrepreneur & 45 & $23 \%$ \\
\hline \multicolumn{2}{|c|}{ Domicile (islands) } \\
\hline
\end{tabular}

\begin{tabular}{|l|l|l|}
\hline Kalimantan & 94 & $47 \%$ \\
\hline
\end{tabular}

\begin{tabular}{|l|c|c|}
\hline Sumatera & 21 & $11 \%$ \\
\hline
\end{tabular}

\begin{tabular}{|l|c|c|}
\hline Jawa & 46 & $23 \%$ \\
\hline
\end{tabular}

\begin{tabular}{|l|c|c|}
\hline Sulawesi & 18 & $9 \%$ \\
\hline Bali & 21 & $11 \%$ \\
\hline
\end{tabular}

\begin{tabular}{|c|c|}
\hline Bali & 21 \\
\hline \multicolumn{3}{|c|}{ Traveling during a pandemic (2020) } \\
\hline
\end{tabular}

\begin{tabular}{|l|c|c|}
\hline \multicolumn{3}{|c|}{ Traveling during a pandemic (2020) } \\
\hline Yes & 153 & $77 \%$ \\
\hline No & 47 & $24 \%$ \\
\hline
\end{tabular}

\begin{tabular}{|l|c|c|}
\hline \multicolumn{3}{|c|}{ Type of tour } \\
\hline Natural tourism & 121 & $80 \%$ \\
\hline
\end{tabular}

\begin{tabular}{|l|c|c|}
\hline Shopping tour & 19 & $13 \%$ \\
\hline
\end{tabular}

\begin{tabular}{|l|c|c|}
\hline Educational tour & 5 & $3 \%$ \\
\hline History tour & 8 & $5 \%$ \\
\hline
\end{tabular}

\begin{tabular}{|l|l|l|}
\hline \multicolumn{3}{|c|}{ Tourist sites } \\
\hline In the city & 58 & $38 \%$ \\
\hline Out &
\end{tabular}

\begin{tabular}{|l|c|c|}
\hline Outside the city within the province & 58 & $38 \%$ \\
\hline
\end{tabular}

Foreign

\begin{tabular}{|l|l|l|}
\hline Outside the province & 6 & $24 \%$ \\
\hline
\end{tabular}

Use of social media

\begin{tabular}{|l|l|l|}
\hline Facebook & 146 & $73 \%$ \\
\hline
\end{tabular}

\begin{tabular}{|l|l|l|}
\hline Instagram & 159 & $80 \%$ \\
\hline
\end{tabular}

\begin{tabular}{|l|c|c|}
\hline WhatsApp & 189 & $95 \%$ \\
\hline$Y$ Oulube
\end{tabular}

\begin{tabular}{|l|c|c|}
\hline Youtube & 76 & $38 \%$ \\
\hline
\end{tabular}

\begin{tabular}{|l|c|c|}
\hline Twiter & 73 & $37 \%$ \\
\hline
\end{tabular}

Tiktok

\begin{tabular}{|l|c|c|}
\hline Telegram & 3 & $2 \%$ \\
\hline Intensity of 'upload status' & 98 & $49 \%$ \\
\hline
\end{tabular}

Social media duration (hours)

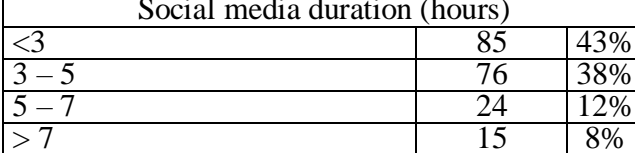

\begin{tabular}{ll}
$5-7$ & \\
\hline
\end{tabular}

\begin{tabular}{|l|r|r|}
\hline \multicolumn{4}{|c|}{ Desire to travel in the future } \\
\hline No & 12 & $6 \%$ \\
\hline$Y$ & 188 & $9 \%$ \\
\hline
\end{tabular}

\begin{tabular}{|l|c|c|}
\hline Yes & 188 & $94 \%$ \\
\hline
\end{tabular}

Natural tourism

Shopping tour

Educational tour

History tou

\begin{tabular}{|l|l|l|}
\hline \multicolumn{3}{|c|}{ Travel plans (months) } \\
\hline$<3$ & 20 & $11 \%$ \\
\hline $3-6$ & 47 & $25 \%$ \\
\hline $6-9$ & 41 & $22 \%$ \\
\hline $9-12$ & 80 & $43 \%$ \\
\hline
\end{tabular}

\begin{tabular}{|c|c|}
\hline $9-12$ & 80 \\
\hline & Tourist location you want to visit \\
\hline
\end{tabular}

\begin{tabular}{|l|r|}
\hline In the city & 32 \\
\hline
\end{tabular}

\begin{tabular}{|l|l|l|}
\hline Outside the city within the province & 40 & $21 \%$ \\
\hline
\end{tabular}

\begin{tabular}{|l|c|c|}
\hline Foreign & 17 & $9 \%$ \\
\hline
\end{tabular}

\begin{tabular}{|l|r|r}
\hline Outside the province & 99 & $53 \%$ \\
\hline
\end{tabular} Traveling during a pandemic

\begin{tabular}{|l|l|l|}
\hline & 20 & $10 \%$ \\
\hline
\end{tabular}

\begin{tabular}{|l|c|c|}
\hline Stay safe with health protocols & 118 & $59 \%$ \\
\hline
\end{tabular}

\begin{tabular}{|l|c|c|}
\hline Not safe & 57 & $29 \%$ \\
\hline
\end{tabular}

Fun

Abstain 
Testing the reliability of the instrument with construct reliability shows the instrument is reliable. Construct reliability that meets the acceptable limits shows this. All indicators connected to the variables are reliable. The estimation results and the fit model (one-step approach to SEM) with AMOS 21 software confirm that the Goodness of Fit (GoF) criteria still do not meet the Cut off Value $(\mathrm{CoV})$. It must change the model under the applicable provisions in AMOS by correlating the gradual errors starting from the largest value (Figure 2). Table 6 summarizes that there are five GoF criteria that have met $\mathrm{CoV}$, so we can conclude that we also built this study with an excellent model.

The causality test in Table 7 shows that the CR value for proving the hypothesis must be above 1.96. The first hypothesis, the second hypothesis, the third hypothesis, and the fourth hypothesis have a positive and significant effect (proven). Table 8 highlights the indirect effect of traveling interest, which can mediate positively and significantly on the relationship between traveling need, safety during traveling, and existence on social need for traveling intention.

A positive estimate value ( $C R>1.96$ showed the proof). The moderation test devoted to the family economic condition variable, whether its role can strengthen the relationship between traveling interest and traveling intention. After modifying the indices, it generated GoF (Table 9). Figure 3 and Table 10 conclude that over five GoF assumptions have met CoV, so that the output for the evaluation results represents a suitable model. The projection of causality in Table 10 shows that family economic conditions can strengthen the relationship between traveling interest and traveling intention. Get an estimate of 0.005 with a CR of 4.766 or above 1.96 . A positive result implies the nature of the family economic condition to strengthen the impact of traveling interest on traveling intention. We conclude that the fifth hypothesis has proven.

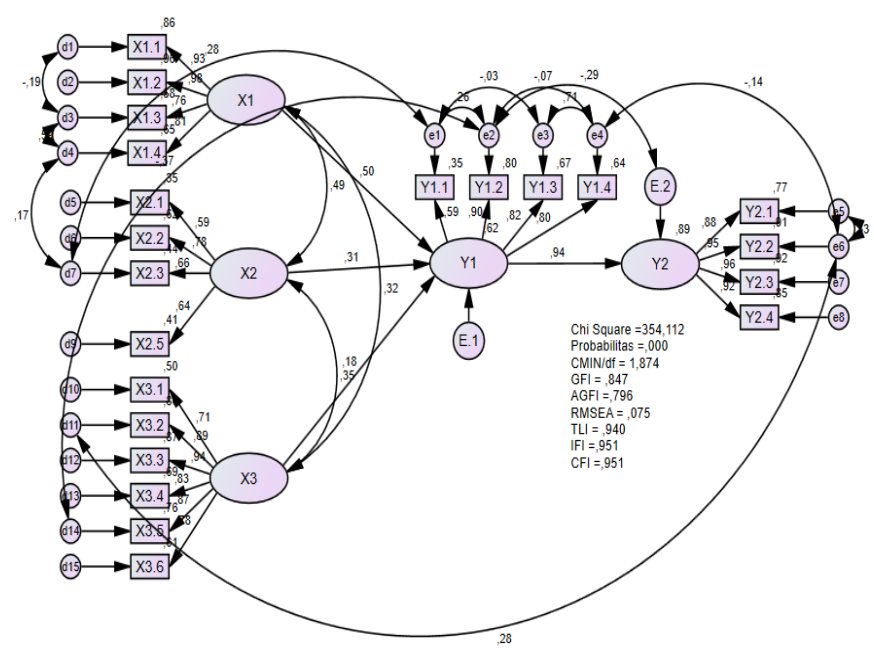

Figure 2. Structural Models (Source: observation by Author's)

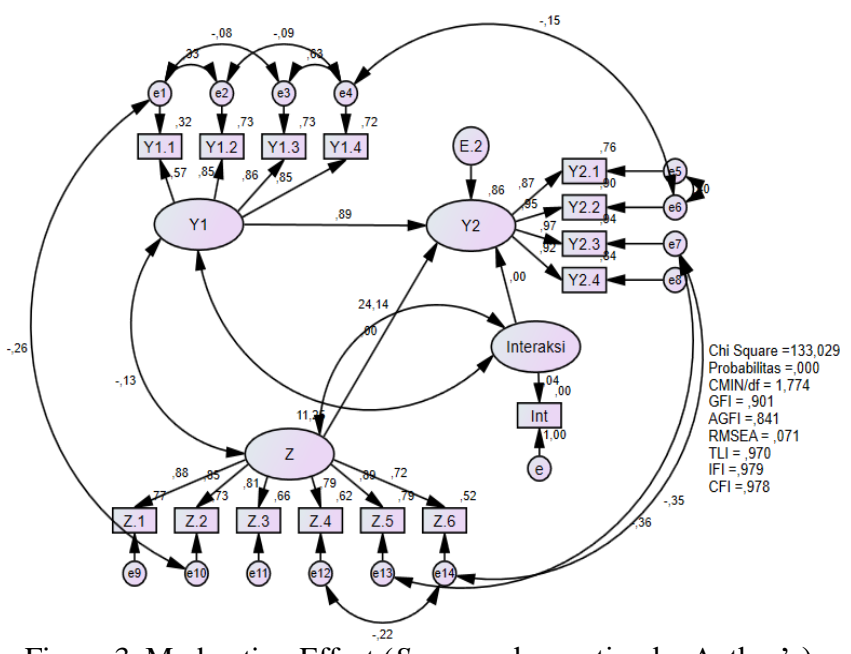

Figure 3. Moderation Effect (Source: observation by Author's)

Table 5. Construct Reliability (Source: observation by Author's)

\begin{tabular}{|c|c|c|c|c|c|}
\hline Variables & Indicators & \begin{tabular}{|l|} 
Standardized \\
factor loading
\end{tabular} & $\begin{array}{c}\text { SFL2 } \\
\text { (perception) }\end{array}$ & $\begin{array}{c}\text { Error } \\
{[\varepsilon j]}\end{array}$ & $\begin{array}{l}\text { Construct } \\
\text { reliability }\end{array}$ \\
\hline \multirow{4}{*}{$\begin{array}{l}\text { Traveling } \\
\text { need (X1) }\end{array}$} & $\mathrm{X} 1.1$ & 0.927 & 0.859 & 0.141 & \multirow{5}{*}{0.931} \\
\hline & $\mathrm{X} 1.2$ & 0.969 & 0.939 & 0.061 & \\
\hline & $\mathrm{X} 1.3$ & 0.779 & 0.607 & 0.393 & \\
\hline & $\mathrm{X} 1.4$ & 0.830 & 0.689 & 0.311 & \\
\hline \multicolumn{2}{|c|}{ Total } & 3.505 & 3.094 & 0.906 & \\
\hline \multirow{4}{*}{$\begin{array}{l}\text { Safety } \\
\text { during } \\
\text { traveling } \\
\text { (X2) }\end{array}$} & $\mathrm{X} 2.1$ & 0.608 & 0.370 & 0.630 & \multirow[t]{5}{*}{0.775} \\
\hline & $\mathrm{X} 2.2$ & 0.771 & 0.594 & 0.406 & \\
\hline & $\mathrm{X} 2.3$ & 0.701 & 0.491 & 0.509 & \\
\hline & $\mathrm{X} 2.5$ & 0.637 & 0.406 & 0.594 & \\
\hline \multicolumn{2}{|c|}{ Total } & 2.717 & 1.861 & 2.139 & \\
\hline \multirow{6}{*}{$\begin{array}{l}\text { Exsist on } \\
\text { socmed } \\
\text { need (X3) }\end{array}$} & X3.1 & 0.711 & 0.506 & 0.494 & \multirow[t]{7}{*}{0.935} \\
\hline & $\mathrm{X} 3.2$ & 0.901 & 0.812 & 0.188 & \\
\hline & X3.3 & 0.934 & 0.872 & 0.128 & \\
\hline & X3.4 & 0.830 & 0.689 & 0.311 & \\
\hline & $\mathrm{X} 3.5$ & 0.876 & 0.767 & 0.233 & \\
\hline & X3.6 & 0.779 & 0.607 & 0.393 & \\
\hline \multicolumn{2}{|c|}{ Total } & 5.031 & 4.253 & 1.747 & \\
\hline \multirow{4}{*}{$\begin{array}{l}\text { Traveling } \\
\text { interest } \\
\text { (Y1) }\end{array}$} & Y1.1 & 0.558 & 0.311 & 0.689 & \multirow[t]{5}{*}{0.888} \\
\hline & Y1.2 & 0.828 & 0.686 & 0.314 & \\
\hline & $\mathrm{Y} 1.3$ & 0.928 & 0.861 & 0.139 & \\
\hline & Y1.4 & 0.909 & 0.826 & 0.174 & \\
\hline \multicolumn{2}{|c|}{ Total } & 3.223 & 2.684 & 1.316 & \\
\hline \multirow{4}{*}{$\begin{array}{l}\text { Traveling } \\
\text { intention } \\
\text { (Y2) }\end{array}$} & Y2.1 & 0.901 & 0.812 & 0.188 & \multirow[t]{5}{*}{0.964} \\
\hline & $\mathrm{Y} 2.2$ & 0.960 & 0.922 & 0.078 & \\
\hline & $\mathrm{Y} 2.3$ & 0.955 & 0.912 & 0.088 & \\
\hline & $\mathrm{Y} 2.4$ & 0.916 & 0.839 & 0.161 & \\
\hline \multicolumn{2}{|c|}{ Total } & 3.732 & 3.484 & 0.516 & \\
\hline \multicolumn{5}{|c|}{ Tolerance limit } & $\geq 0.7$ \\
\hline
\end{tabular}

Table 6. GoF after Modification Indices (Source: Author's)

\begin{tabular}{|l|c|c|l|}
\hline \multicolumn{1}{|c|}{ Criteria } & Result & $\boldsymbol{C o} \boldsymbol{V}$ & Evaluation \\
\hline CMIN/DF & 1.874 & $\leq 2.00$ & Good fit \\
\hline RMSEA & 0.075 & $\leq 0.08$ & Good fit \\
\hline GFI & 0.847 & $\geq 0.90$ & Marginal fit \\
\hline AGFI & 0.796 & $\geq 0.90$ & Bad fit \\
\hline TLI & 0.940 & $\geq 0.90$ & Good fit \\
\hline CFI & 0.951 & $\geq 0.90$ & Good fit \\
\hline IFI & 0.951 & $\geq 0.90$ & Good fit \\
\hline
\end{tabular}

Table 7. Direct Hypothesis Testing (Source: Author's)

\begin{tabular}{|l|c|c|c|c|}
\hline \multicolumn{1}{|c|}{ Effects } & Estimate & SE & CR & P \\
\hline $\begin{array}{l}\text { Traveling need (X1) } \rightarrow \\
\text { Traveling interest (Y1) }\end{array}$ & 0.290 & 0.058 & 5.010 & 0.000 \\
\hline $\begin{array}{l}\text { Safety during traveling (X2) } \\
\rightarrow \text { Traveling interest (Y1) }\end{array}$ & 0.269 & 0.084 & 3.201 & 0.001 \\
\hline $\begin{array}{l}\text { Exsist on socmed need (X3) } \\
\rightarrow \text { Traveling interest (Y1) }\end{array}$ & 0.080 & 0.031 & 2.629 & 0.009 \\
\hline $\begin{array}{l}\text { Traveling interest (Y1) } \rightarrow \\
\text { Traveling intention (Y2) }\end{array}$ & 1.630 & 0.222 & 7.353 & 0.000 \\
\hline
\end{tabular}

Table 8. Indirect Hypothesis Testing (Source: Author's)

\begin{tabular}{|l|c|c|c|c|}
\hline \multicolumn{1}{|c|}{ Effects } & Estimate & S.E. & CR & P \\
\hline $\begin{array}{l}\text { Traveling Need (X1) } \rightarrow \\
\text { Traveling interest (Y1) } \\
\text { Traveling intention (Y2) }\end{array}$ & 0.473 & 0.114 & 4.133 & 0.000 \\
\hline $\begin{array}{l}\text { Safety during traveling (X2) } \\
\rightarrow \text { Traveling interest (Y1) } \\
\rightarrow \text { Traveling intention (Y2) }\end{array}$ & 0.438 & 0.149 & 2.935 & 0.004 \\
\hline $\begin{array}{l}\text { Exsist on socmed need (X3) } \\
\rightarrow \text { Traveling interest (Y1) } \\
\rightarrow \text { Traveling intention (Y2) }\end{array}$ & 0.130 & 0.054 & 2.435 & 0.016 \\
\hline
\end{tabular}


Table 9. Post-Modification GoF Indices for Moderation (Source:Author's)

\begin{tabular}{|c|c|c|c|}
\hline Criteria & Result & CoV & Evaluation \\
\hline CMIN/DF & 1.774 & $\leq 2.00$ & Good fit \\
\hline RMSEA & 0.071 & $\leq 0.08$ & Good fit \\
\hline GFI & 0.901 & $\geq 0.90$ & Good fit \\
\hline AGFI & 0.841 & $\geq 0.90$ & Marginal fit \\
\hline TLI & 0.970 & $\geq 0.90$ & Good fit \\
\hline CFI & 0.978 & $\geq 0.90$ & Good fit \\
\hline IFI & 0.979 & $\geq 0.90$ & Good fit \\
\hline
\end{tabular}

Table 10. Hypothesis Testing with Moderation (Source: observation by Author's)

\begin{tabular}{|c|c|c|c|c|}
\hline Effects & Estimate & SE & CR & P \\
\hline $\begin{array}{c}\text { Interaction } \rightarrow \text { Traveling } \\
\text { intention (Y2) }\end{array}$ & 0.005 & 0.001 & 4.766 & 0.000 \\
\hline
\end{tabular}

\section{DISCUSSION}

Basically, everyone has a need for tourism activities. By traveling, boredom and stress will disappear. One's soul gets an injection of energy to get back into the routine of work, so that it is stronger in accepting the pressures and challenges that come. Tourism is a necessity for everyone in all segments, without exception. Especially when the Covid-19 pandemic hit Indonesia, where they experienced fear and boredom because there were many activity restrictions and outrageous requests for referrals to tourism activities. Tourism also serves to increase the body's immunity. It aligned needs with a person's interest to fulfill them. In this study, we also proved that the need for tourism has a positive effect on the interest in doing tourism. The higher the need for tourism activities, the more interest in traveling. This is in line with previous findings by Huang and Tsai (2003), Saifudin and Puspita (2020), and Gilbert and Terrata (2001).

Traveling aims to refresh the individual physically and psychologically. This has become a primary need that as much as possible to be met. However, during this pandemic, travel activities hindered by safety issues, where they are afraid of being exposed to Covid-19. Therefore, safety is an important key to be considered when traveling. It is in the spotlight for the managers of a destination to ensure that when visiting; the management remains safe from transmission of the virus. In various destinations, there are also adequate health protocol facilities and officers who are always alert to health protocols. Tourism owners implement various strategies to prevent transmission, for example by restricting visitors, checking body temperature, and warnings to always maintain cleanliness by washing hands or using hand sanitizer.

The perception of safety during a trip has a significant effect on a person's interest in traveling. From the more tourists feel safe during their trip, the greater their interest in visiting. The relevance of this finding is in line with the study of Liu et al. (2016), Lindqvist and Björk (2000), and Yang and Nair (2014).

Social media has become a part of internet users. With a variety of uses, initially as a forum for socializing and the emergence of social media as a promotional media for products, so many famous people appear from social media. Those who had known on social media have a lot of subscribers and followers, so there will be a lot of financial benefits from what they endorse. The more famous a person is, the more expensive the rate will be (Reisinger and Mavondo, 2005).

Nowadays, many social media activists are competing to exist or show themselves through the accounts they have. The audience will like with interesting content through the materials they upload, especially those based on tourism by visiting a destination as a vlog. The tourism favored by the public is culinary tourism, nature tourism, and nature tourism. Travel content, apart from trying to provide entertainment with uploaded materials, also displays the lifestyle they want to show to others. The greater the desire of netizens to exist on social media, the more they support their interest in traveling.

In the response hierarchy, intentions and interests together form the affective stage, where the first step is the interest step. When motivation increases, this interest will turn into an applied intention so that the intention is close to the behavior stage or action stage. In tourism, interest in traveling will encourage internal and external factors. For example, they bore someone with the routine conditions of work and divert it by traveling, while external factors such as an invitation from a friend or exposure to information got from various exported media (Sharma et al., 2020). The emergence of interest in traveling, the greater the interest got for traveling (Tung and Ritchie, 2011). Interest will turn into an intention when the motivation and sufficient resources to realize it. The resources in question are as money, time, and other support systems. In the case study, the economic condition of the family increases a person's intention to travel. The aspect that is highlighted is the readiness of the budget. It closely related the tourism sector to the economic sector. When a family still bothered by physiological needs, it is less likely to set aside a budget for travel (Archer and Fletcher, 1996).

The argument that needs to be built regarding the impact of Covid-19 that has spread to the existence of the tourism industry applies to what is highlighted by Agustina and Yosintha (2021). In Asia, comparison with other regions such as Africa, Australia, Europe, and America is in a more severe trend. Hotel occupancy rates in Asia fell by 57\% which resulted in 63.4 million hotel employees losing their jobs. At least, regulations that prohibit travel activities and temporary closures at tourist attractions also exacerbated this. They estimate losses at US\$ 1,041 million. Worse yet, the impact of Covid-19 has caused people to cancel flight ticket orders and stay overnight. In addition, even in Indonesia, many employees have no income and their welfare has dropped dramatically (Riadil, 2020).

Automatically, the Covid-19 attack also threatens the sustainability of people's lives. The recovery from this deteriorating condition implemented by opening tourist destinations in Indonesia with limited hours and operational protocols. The economic aspect is the dominant motive that needs to be considered because it stops revenues from taxes and tourism services. There needs to promotions through increased facilities, promotions, and price cuts (e.g. Atmojo and Fridayani, 2021; Ardiansyah, 2020). Concentration needs to be focused on issues of access, attractiveness, cost, and facilities so that it becomes a brand image slowly attracts visitors again. 


\section{CONCLUSSION}

The exploratory results have been consistent with testing, that it proves all hypotheses to be acceptable. The three independent variables (traveling need, safety during traveling, and exist on social need) have a positive effect on the dependent variable (traveling intention), and the intervening variable (traveling interest) can carry out its role as a mediator. Likewise, the moderator variable (family economic condition) can strengthen the influence between traveling interest and traveling intention.

Although the effects of the pandemic felt directly by the Indonesian people, they still want to travel in 2021, as reflected by 94 respondents. The most popular and popular nature of tourism preferences. This positive information also shows that the tourism sector still has hope, but on condition that economic conditions must continue to improve in line with the expectations of the wider community. Besides the economy, the government must consider the safety factor. Vaccination programs and strict protocols as part of health procedures to realize the Covid-19 handling strategy that must maintained.

\section{Acknowledgements}

The study was sponsored by an internal grant (Department of Management, Faculty of Economics and Business, Mulawarman University).

\section{REFERENCES}

Agustina, I.T., \& Yosintha, R. (2021). The impact of covid-19 on hotel industry in Asian Countries. Jurnal Kepariwisataan Indonesia: Jurnal Penelitian dan Pengembangan Kepariwisataan Indonesia, 14(2), 159-167. https://doi.org/10.47608/jki.v14i22020.159-167

Ajzen, I., \& Fishbein, M. (1980). Understanding attitudes and predicting social behavior. Englewood Cliffs, NJ: Prentice Hall.

Alegre, J., Cladera, M., \& Sard, M. (2011). Analysing the influence of tourist motivations on tourist expenditure at a sun-and-sand destination. Tourism Economics, 17(4), 813-832. https://doi.org/10.5367/te.2011.0063

Archer, B., \& Fletcher, J.E. (1996). The economic impact of tourism in the Seychelles. Annals of Tourism Research, $23(1), 32-47$. https://doi.org/10.1016/0160-7383(95)00041-0

Ardiansyah, M. (2020). The impact of corona virus disease (covid-19) on Indonesia tourism. Jurnal Media Bina Ilmiah, 15(4), 43214328. https://doi.org/10.33758/mbi.v15i4.888

Atmojo, M.E., \& Fridayani, H.D. (2021). An assessment of covid-19 pandemic impact on Indonesian tourism sector. Journal of Governance and Public Policy, 8(1), 1-9. https://doi.org/10.18196/jgpp.811338

Behl, A., Sheorey, P., Jain, K., Chavan, M., Jajodia, I., \& Zhang, Z. (2021). Gamifying the gig: transitioning the dark side to bright side of online engagement. Australasian Journal of Information Systems, 25, 01-34. https://doi.org/10.3127/ajis.v25i0.2979

Bosnjak, M., Obermeier, D., \& Tuten, T. (2006). Predicting and explaining the propensity to bid in online auctions: a compari son of two action-theoretical models. Journal of Consumer Behaviour, 5(2), 102-116. https://doi.org/10.1002/cb.38

Purba, J.H., Fathiah, R., \& Steven, S. (2021). The impact of covid-19 pandemic on the tourism sector in Indonesia. Riset, 3(1), 389 - 401. https://doi.org/10.35212/riset.v3i1.82

Cohen, J.B., \& Areni, C.S. (1991). Affect and consumer behavior. In: T. S. Robertson \& H. H. Kassarjian (Eds.), Handbook of consumer theory and research (pp. 188-240). Englewood Cliffs, NJ: Prentice Hall.

Doriza, S. (2015). Ekonomi keluarga [Family economy]. Bandung: Remaja Rosdakarya.

Dodds, W.B., Monroe, K.B., \& Grewal, D. (1991). Effects of price, brand, and store information on buyers' product evaluations. Journal of Marketing Research, 28(3), 307-319. https://doi.org/10.1177/002224379102800305

Dwyer, L., Forsyth, P., \& Spurr, R. (2004). Evaluating tourism's economic effects: new and old approaches. Tourism Management, 25(3), 307-317. https://doi.org/10.1016/S0261-5177(03)00131-6

Edosomwan, S., Prakasan, S.K., Kouame, D., Watson, J., \& Seymour, T. (2011). The history of social media and its impact on business. Journal of Applied Management \& Entrepreneurship, 16(3), 79-91. https://www.researchgate.net/publication/303216233_ The_history_of_social_media_and_its_impact_on_business

Fazekas, A., Senn, C.Y., \& Ledgerwood, D.M. (2001). Predictors of intention to use condoms among university women: an application and extension of the theory of planned behavior. Canadian Journal of Behavioural Science, 33(2), 103-117. https://doi.org/10.1037/h0087133

Gelan, A. (2003). Local economic impacts. Annals of Tourism Research, 30(2), 406-425. https://doi.org/10.1016/S0160-7383(02)00098-1

Gilbert, D., \& Terrata, M. (2001). An exploratory study of factors of Japanese tourism demand for the UK. International Journal of Contemporary Hospitality Management, 13(2), 70-78. https://doi.org/10.1108/09596110110381843

Hayes, A.F. (2013). Introduction to mediation, moderation, and conditional process analysis: a regression-based approach. New York City: Guilford Press.

Hemsley, J., Jacobson, J., Gruzd, A., \& Mai, P. (2018). Social media for social good or evil: an introduction. Social Media + Society, 4(3), 205630511878671. https://doi.org/10.1177/2056305118786719

Huang, L., \& Tsai, H.T. (2003). The study of senior traveler behavior in Taiwan. Tourism Management, 24(5), 561-574. https://doi.org/10.1016/S0261-5177(03)00008-6

Ilmi, Z., Darma, D.C., \& Azis, M. (2020). Independence in learning, education management, and industry 4.0: habitat Indonesia during COVID-19. Journal of Anthropology of Sport and Physical Education, 4(4), 63-66. https://doi.org/10.26773/jaspe.201010

Iso-Ahola, S.E. (1980). The social psychology of leisure and recreation. Dubuque, IA: William C Brown Pub.

Jang, S., \& Cai, L.A. (2002). Travel motivations and destination choice: a study of british outbound market. Journal of Travel \& Tourism Marketing, 13(3), 304-324. https://doi.org/10.1080/10548400209511570

Jiuhardi, J., Darma, D.C., \& Heksarini, A. (2021). The political-economy management: Indonesia's needs for the covid-19 pandemic. Problems of Management in the $21^{\text {st }}$ Century 16(1), 19-27. https://doi.org/10.33225/pmc/21.16.19

Kapoor, K.K., Tamilmani, K., Rana, N.P., Patil, P., Dwivedi, Y.K., \& Nerur, S. (2018). Advances in social media research: past, present and future. Information Systems Frontiers, 20(3), 531-558. https://doi.org/10.1007/s10796-017-9810-y

Klijs, J., Heijman, W., Maris, D.K., \& Bryon, J. (2012). Criteria for comparing economic impact models of tourism. Tourism Economics, 18(6), 1175-1202. https://doi.org/10.5367/te.2012.0172

Lindqvist, L.J., \& Björk, P. (2000). Perceived safety as an important quality dimension among senior tourists. Tourism Economics, 6(2), 151-158. https://doi.org/10.5367/000000000101297541 
Liu, B., Pennington-Gray, L., \& Schroeder, A. (2013). Image of safe tourism destinations in the United States held by African Americans. PASOS. Revista de Turismo y Patrimonio Cultural, 11(3), 105-121. https://riull.ull.es/xmlui/handle/915/14973

Liu, B., Schroeder, A., Pennington-Gray, L., \& Farajat, S.A. (2016). Source market perceptions: How risky is Jordan to travel to? Journal of Destination Marketing \& Management, 5(4), 294-304. https://doi.org/10.1016/j.jdmm.2016.08.005

Maria, S., Pusriadi, T., Hakim, Y.P., \& Darma, D.C. (2019). The effect of social media marketing, word of mouth, and effectiveness of advertising on brand awareness and intention to buy. Jurnal Manajemen Indonesia, 19(2), 107-122. https://doi.org/10.25124/jmi.v19i2.2234

Maslow, A.H. (1943). A theory of human motivation. Psychological Review, 50(4), 370-396. https://doi.org/10.1037/h0054346

Nasrullah, R. (2018). Public digital research: media perspective and virtual reality in social media. Jurnal Sosioteknologi, 17(2), $271-287$. https://doi.org/10.5614/sostek.itbj.2018.17.2.9

Navy, S.L. (2020). Theory of human motivation-Abraham Maslow. In: Akpan B., Kennedy T.J. (eds) Science Education in Theory and Practice. Springer Texts in Education. Springer, Cham. https://doi.org/10.1007/978-3-030-43620-9_2

Parahita, G.D. (2019). The rise of Indonesian feminist activism on social media. Jurnal Komunikasi Ikatan Sarjana Komunikasi Indonesia, 4(2), 104-115. https://doi.org/10.25008/jkiski.v4i2.331

Perez, E.A., \& Juaneda, S.C. (2000). Tourist expenditure for mass tourism markets. Annals of Tourism Research, 27(3), 624-637. https://doi.org/10.1016/S0160-7383(99)00101-2

Pusriadi, T., Ilmi, Z., Kadarusman, K., Kurniawan, E., \& Darma, D.C. (2021). Ethical work climate and moral awareness during Covid-19 - a case study. Annals of Contemporary Developments in Management \& HR, 3(1), 11-23. https://doi.org/10.33166/ACDMHR.2021.01.002

Rahmawati, R., Oktora, K., Ratnasari, S.L., Ramadania, R., \& Darma, D.C. (2021). Is it true that Lombok deserves to be a halal tourist destination in the world? a perception of domestic tourists. GeoJournal of Tourism and Geosites, 34(1), 94-101. https://doi.org/10.30892/gtg.34113-624

Ramadania, R., Fatih, Y.A., Darma, D.C., \& Fauziah, F. (2021). Millennials and traveling to domestic destination. GeoJournal of Tourism and Geosites, 35(2), 398-405. https://doi.org/10.30892/gtg.35218-664

Reisinger, Y., \& Mavondo, F. (2005). Travel anxiety and intentions to travel internationally: implications of travel risk perception. Journal of Travel Research, 43(3), 212-225. https://doi.org/10.1177/0047287504272017

Riadil, I.G. (2020). Tourism industry crisis and its impacts: Investigating the Indonesian tourism employees perspectives' in the pandemic of covid-19. Jurnal Kepariwisataan: Destinasi, Hospitalitas dan Perjalanan, 4(2), 1-15. https://doi.org/10.34013/jk.v4i2.54

Ringle, C.M., Sarstedt, M., Mitchell, R., \& Gudergan, S.P. (2020). Partial least squares structural equation modeling in HRM research. The International Journal of Human Resource Management, 31(12), 1617-1643. https://doi.org/10.1080/09585192.2017.1416655

Rittichainuwat, B.N., \& Chakraborty, G. (2009). Perceived travel risks regarding terrorism and disease: the case of Thailand. Tourism Management, 30(3), 410-418. https://doi.org/10.1016/j.tourman.2008.08.001

Saifudin, S., \& Puspita, R. (2020). Predicting the intention of millennial moslems to visit halal tourism. Equilibrium: Jurnal Ekonomi Syariah, 8(1), 129-142. http://dx.doi.org/10.21043/equilibrium.v8i1.7322

Sharma, S., Singh , G., \& Pratt, S. (2020). Does Consumers' Intention to Purchase Travel Online Differ Across Generations? Empirical Evidence from Australia. Australasian Journal of Information Systems, 24, 01-31. https://doi.org/10.3127/ajis.v24i0.2751

Sirakaya, E., Sheppard, A.G., \& McLellan, R.W. (1997). Assessment of the relationship between perceived safety at a vacation site and destination choice decisions: extending the behavioral decision-making model. Journal of Hospitality \& Tourism Research, 21(2), 110. https://doi.org/10.1177/109634809702100201

Slovic, P., \& Peters, E. (2006). Risk perception and affect. Current Directions in Psychological Science, 15(6), 322-325. https://doi.org/10.1111/j.1467-8721.2006.00461.x

Sönmez, S.F., \& Graefe, A.R. (1998). Determining future travel behavior from past travel experience and perceptions of risk and safety. Journal of Travel Research, 37(2), 171-177. https://doi.org/10.1177/004728759803700209

Syahputra, I., \& Hafiar, H. (2019). Activities of netizens on social media and religious spirituality of Indonesian millennials in the era of new media. The International Journal of Religion and Spirituality in Society, 9(1), 57-70. https://doi.org/10.18848/21548633/CGP/v09i01/57-70

Tung, V.W., \& Ritchie, J.R. (2011). Exploring the essence of memorable tourism experiences. Annals of Tourism Research, 3(4), 13671386. https://doi.org/10.1016/j.annals.2011.03.009

Witte, K., Cameron, K.A., McKeon, J.K., \& Berkowitz, J.M. (1996). Predicting risk behaviors: development and validation of a diagnostic scale. Journal of Health Communication, 1(4), 317-341. https://doi.org/10.1080/108107396127988

Yang, E.C., \& Nair, V. (2014). Risk perception study in tourism: are we really measuring perceived risk?. Procedia - Social and Behavioral Sciences, 144, 322-327. https://doi.org/10.1016/j.sbspro.2014.07.302

Yuan, S., \& Mcdonald, C. (1990). Motivational determinates of international pleasure time. Journal of Travel Research, 29(1), 42-44. https://doi.org/10.1177/004728759002900109

Zafar, Q.U., \& Rafique, M. (2013). Impact of celebrity advertisement on customers brand perception and purchase intention. Asian Journal of Business and Management Sciences, 1(11), 53-67. https://www.academia.edu/25289854/Impact_of_Celebrity_ Advertisement_on_Customers_Brand_Perception_and_Purchase_Intention

*** Central Statistics Agency of Indonesia. (2020). Survei dampak COVID-19 terhadap pelaku usaha jilid II [Survey on the impact of COVID-19 on business actors volume II]. Retrieved from https://covid-19.bps.go.id/ in June 24, 2021.

*** The Kompas. (2020). Survei: minat liburan saat pandemi besar, wisata laut jadi incaran [Survey: holiday interest during a major pandemic, marine tourism is the target]. Travel. https://travel.kompas.com/read/2020/12/10/210000627/survei-minat-liburan-saatpandemi-besar-wisata-laut-jadi-incaran

*** The SMRC. (2020). SMRC: $71 \%$ masyarakat nilai ekonomi rumah tangga memburuk saat pandemi [SMRC: $71 \%$ of the community's household economic value worsens during the pandemic]. Berita. https://katadata.co.id/agungjatmiko/berita/ 5ef47ac5cd60b/smrc-71-masyarakat-nilai-ekonomi-rumah-tangga-memburuk-saat-pandemi

*** World Health Organization. (2021). Terms of reference of the WHO COVID-19 infection prevention and control research working group. Overview. https://www.who.int/publications/m/item/terms-of-reference-of-the-who-covid-19-infection-prevention-andcontrol-research-working-group in June 21, 2021 